\title{
Development of Occupational Safety, Health (K3) Courses for Makeup Students in the Engineering Faculty of the State University of Medan
}

\author{
Siti Wahidah ${ }^{1}$, Nur Basuki ${ }^{2}$, Lina Pangaribuan ${ }^{3}$ \\ \{sitiwahidahrias@gmail.com¹,nurbasuki@unimed.ac.id², linapangaribuan@unimed.ac.id ${ }^{3}$ \} \\ Faculty of Engineering, Medan State University, Indoensia ${ }^{1,2,3}$ \\ sitiwahidahrias@gmail.com
}

\begin{abstract}
This study aims to (1) develop appropriate learning modules in the Safety, Occupational and Environmental Health subjects for students of Makeup Education at the Faculty of Engineering, State University of Medan, and (2) determine the feasibility of the Safety, Occupational Health and Environmental learning modules for students Make-Up Education Faculty of Engineering, State University of Medan. This research is development research in the form of developing learning materials for safety, occupational health and the environment using the 4D Models method, namely (1) Define, (2) Design, (3) Development, (4) Disseminate which contains 14 learning activities. Data collection methods involve a material expert and media expert. Field test of the product was carried out on makeup students of the Faculty of Engineering, State University of Medan, Odd Semester. Data analysis techniques used the Likert-4 scale using quantitative descriptive analysis. The results of the development show that the learning media products in the form of Learning Module for Safety, Occupational Health, and the Environment get a value of 141 out of a total of 169 with the category Very Eligible from Material Experts and have an average percentage of $85.20 \%$. The assessment from media experts got a score of 150 out of a total of 161 in the Very Eligible category and had an average percentage of $94.83 \%$. While for the product field test, respondents gave a value of 109.3 out of a total of 136 in the Eligible category and had an average percentage of $80 \%$. In the field test is the aspects.
\end{abstract}

Keywords: K3L, Modules, Makeup Education.

\section{Introduction}

The makeup study program at the Faculty of Engineering, Medan State University (Unimed) is one of the study programs in the PKK Department. The makeup study program at the Faculty of Engineering Unimed makes the K3 course one of the mandatory courses taken in the first semester by new students. The goal is that students have more preparation in terms of safety, personal health and the environment when entering the workforce amidst the changing times of the increasingly modern era of industrialization. Work accidents (work accident) will result in a loss effect (loss) no matter how much. Therefore as much as possible work accidents should be prevented, if possible can be eliminated, or at least reduced the impact.

$\mathrm{K} 3$ as one of the compulsory subjects considered very important encountered several obstacles in the delivery process. From the results of interviews conducted with the Occupational Health Safety Lecturer (K3) Lecturer on Unimed Makeup Cosmetics and 
a number of students who have taken the course, information is obtained that the obstacle is the unavailability of complete learning media that contains material in accordance with the RPS for K3 Courses Cosmetology Education. Students who have taken the K3 Course have complained about the lack of practical learning resources that can be used as a reference for independent learning. While the results of observations of students during the K3 lecture process found that students seemed less enthusiastic about lectures due to lack of learning resources.

With this learning module can be used as a guide by students in conducting K3 lectures, which so far have not used specific print learning media. The development of instructional media through this module is also expected to be able to increase the activity and independence as well as student responses. K3 material is one of the courses that not only contains understanding material but also requires a strong character planting so that $\mathrm{K} 3$ culture will automatically be created. Based on the description, the researcher wants to develop learning media in the form of K3 course modules for Students of Make Up Education, Faculty of Engineering, State University of Medan.

\section{Research Method}

This research is a development research. The purpose of this study is to determine the development and feasibility of the Occupational Health Safety course module for students in Makeup Education. The development model that is used as a reference in the development of Work Health Safety course modules for Students of Faculty Engineering in Makeup Education is the 4-D development model. The reason for using this development model is because the development process is simpler and more coherent.

This 4-D development model includes the following stages: (1) Define contains the initial analysis stage (front-end-analysis), learner analysis, task analysis, concept analysis, and formulating learning objectives. (2) Design includes the stage of preparing a benchmark reference test (constructing criterion-referenced test), the stage of media selection, selection of format, and making the initial design. (3) The development stage includes the stage of expert appraisal and developmental testing. (4) Disseminate is the product distribution stage.

This development research procedure refers to the 4-D research and development steps (. Referring to the literature review that has been discussed, development steps are made as shown in Figure. 


\begin{tabular}{|l|l|}
\hline 1 & $\begin{array}{l}\text { Preliminary Analysis / Identification of } \\
\text { Needs }\end{array}$ \\
\hline 2 & Student Analysis and Curriculum \\
\hline 3 & Concept and Task Formulation \\
\hline 4 & Concept and Task Formulation \\
\hline
\end{tabular}

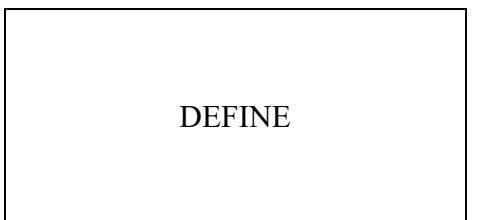

\begin{tabular}{|l|l|}
\hline 1 & Outlining the Module Content \\
\hline 2 & Making the contents of the Module Design \\
\hline 3 & Selection of Learning Module Format \\
\hline 4 & Module Writing (Draft I) \\
\hline
\end{tabular}

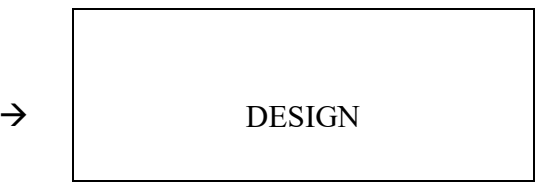

\begin{tabular}{|l|l|}
\hline 1 & Material and Media Expert Validation \\
\hline 2 & Revision I \\
\hline 3 & Results of Revision (Draft II) \\
\hline 4 & Development Trial \\
\hline 5 & Revision II \\
\hline 6 & Module K3 \\
\hline
\end{tabular}

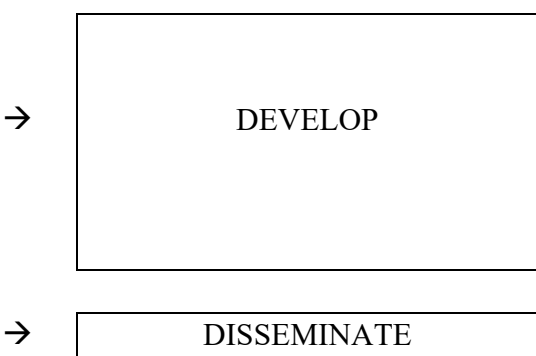

\begin{tabular}{l|l|l}
\hline 1 & Spread & $\rightarrow$ \\
\hline
\end{tabular}

Figure 2.1. Steps for K3 Learning Module Development

\section{Results and Discussion}

The results of the validation of material experts, media experts and validation of development trials to see the feasibility of OSH courses can be seen as follows.

\section{a. Material Expert and Media Expert Validation}

This validation was carried out by material experts using an assessment questionnaire that included aspects of self instruction, self contained, stand alone, adaptive and user friendly. The results of validation tests that have been carried out on the aspect of self instruction by material experts get a value of 86 with a minimum assessment interval of 26 and a maximum value of 104 , with a very decent interval assessment category and have a percentage of assessment of $88.49 \%$. Judging from the aspects of self contained by the material experts get a value of 16 with a minimum assessment interval of 4 and a maximum value of 16 , with a very decent interval evaluation category and has a percentage rating of $100 \%$. Judging from the stand alone aspect by the material experts get a value of 12 with an assessment interval of a minimum value of 4 and a maximum value of 16 , with a very decent interval assessment category and has a percentage rating of $75 \%$. Judging from the adaptive aspects by the material experts get a value of 12 with a minimum assessment interval of 4 and a maximum value of 16 , with a very decent interval evaluation category and has a percentage rating of $75 \%$. Judging from the user friendly aspects by the material experts get a value of 14 with a minimum assessment interval of 4 and a maximum value of 16 , with a very decent interval assessment category and has an assessment percentage of $88 \%$. Overall, from the assessment conducted on aspects of self instruction, self 
contained, stand alone, adaptive and user friendly, the overall value of the validity of the material experts is 140 from a minimum interval of 42 and a maximum value of 168, the K3 learning module is categorized as Very Eligible, with a percentage total valuation of $84.20 \%$.

Validation testing is carried out by media experts using an assessment questionnaire that including aspects of format, organization, attractiveness, shape and size of letters, space (blankspaces) and consistency. The results of validation tests that have been carried out on the aspect of formatting by media experts get a value of 22 with an assessment interval of a minimum value of 6 and a maximum value of 24, with a very decent interval assessment category and have a percentage rating of $92 \%$. Judging from the aspect of organization by media experts get a value of 29 with a minimum assessment interval of 8 and a maximum value of 32, with a very decent interval evaluation category and has a percentage rating of $91 \%$. Judging from the aspect of attractiveness by the media experts get a value of 27 with a minimum assessment interval of 8 and a maximum value of 32, with a very decent interval assessment category and has an assessment percentage of $84 \%$. Judging from the aspect of the shape and size of the letters by media experts get a value of 24 with a minimum value of 6 intervals and a maximum value of 24 , with a very decent interval evaluation category and has a percentage rating of $100 \%$. Judging from the aspect of space (blank space) by media experts get a value of 23 with a minimum assessment interval of 6 and a maximum value of 24, with a very decent interval assessment category and has a percentage rating of $96 \%$.

Judging from the aspect of consistency by media experts get a value of 24 with an assessment interval of at least 6 and a maximum value of 24, with a very decent interval assessment category and has a percentage rating of $100 \%$. Overall from the assessments that have been carried out on aspects of format, organization, attractiveness, shape and size of letters, and consistency, the overall value of validity obtained from media experts is 149 from a minimum value interval of 40 and a maximum value of 160 , the $\mathrm{K} 3$ learning module is categorized as Very Eligible, with percentage of total valuation of $94.83 \%$.

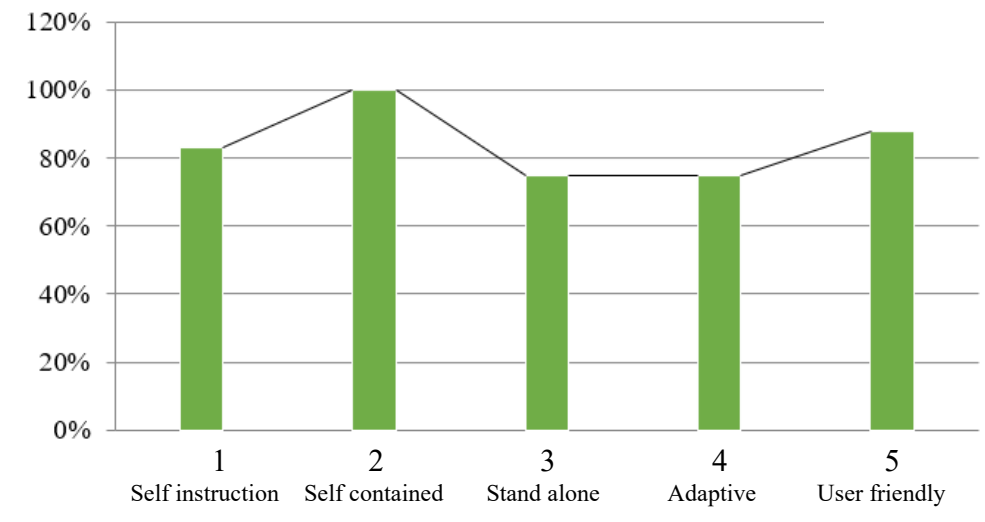

Fig 1. Bar Diagram of Material Expert Validation Results

\section{b. Media Expert Validation}

The results of the material expert evaluation are based on the average number of aspects of format, organization, attractiveness, shape and size of letters, blank space and consistency of 149 from a maximum score of 160 with a percentage of $93.83 \%$. In accordance with Table 35 it can be classified that the total score of material experts is included in the Very Eligible 
category. In addition there are of course some input and suggestions from the validator to make some improvements to the media before being used as a learning medium. The results of the expert material evaluation in the form of a bar diagram are illustrated as follows:

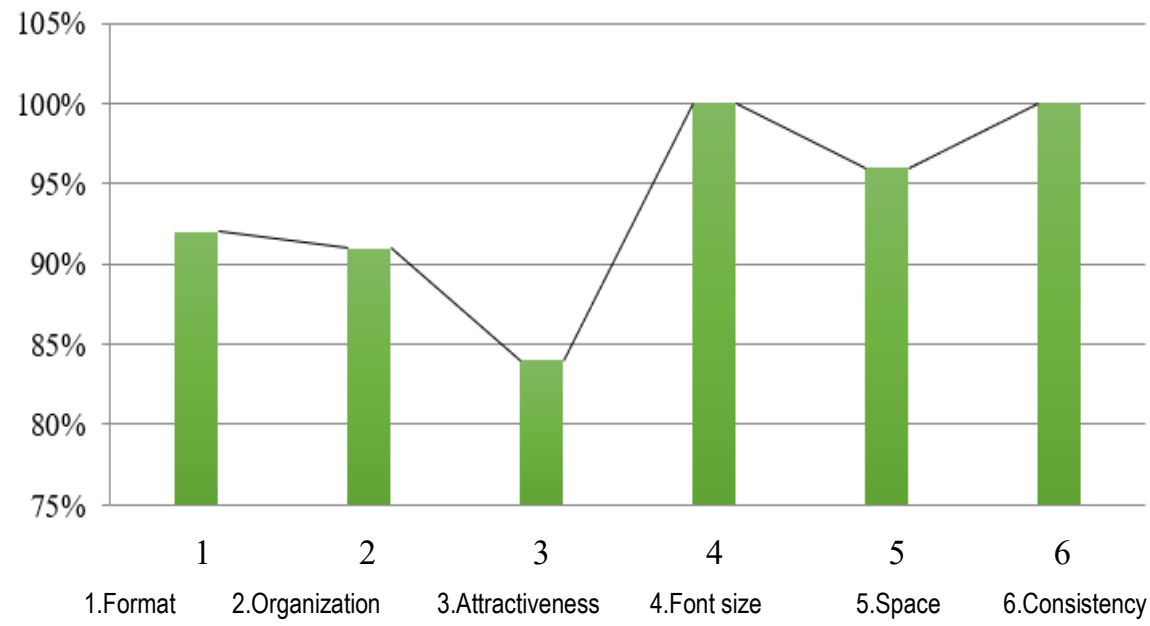

Fig 2. Bar Diagram of Media Expert Validation Results

\section{2) Field Test Result}

Instruments that have been declared valid and reliable can be used as material for evaluating learning media to get the data results accordingly

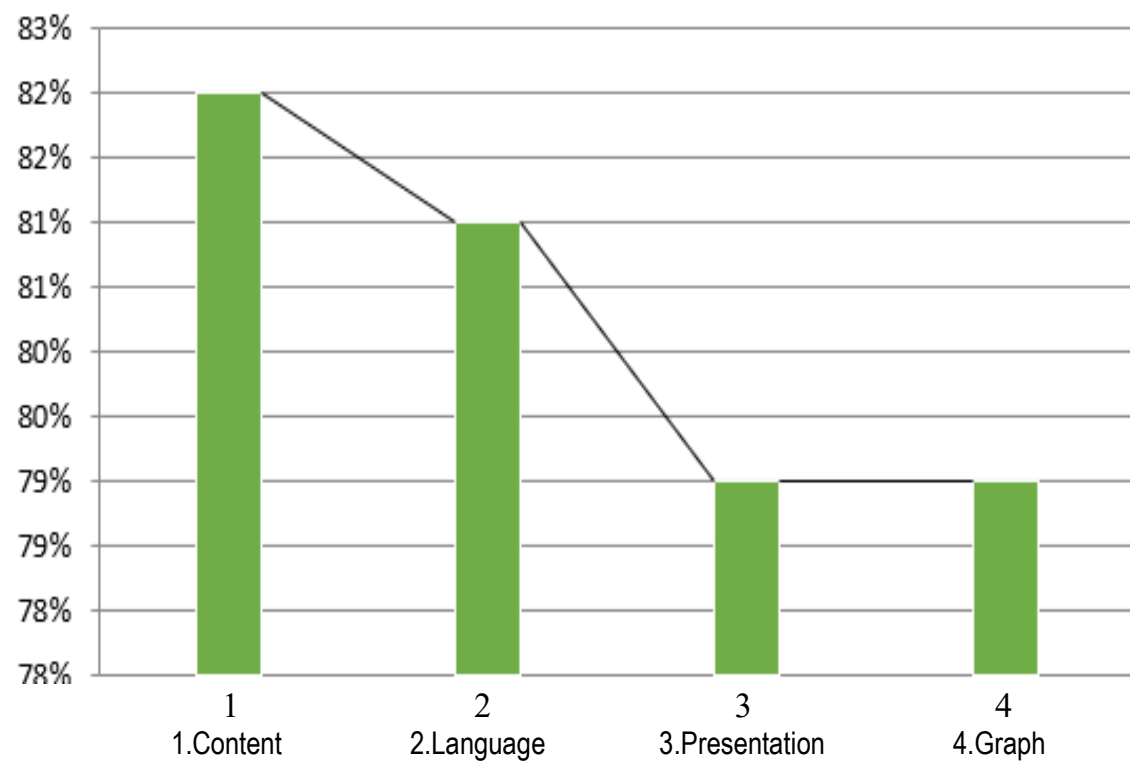

Fig 3. Field Diagram of Field Test Results 


\section{Conclussion}

The results of this research show that the learning media products as Learning Module for Safety, Occupational Health, and the Environment get a value of 141 out of a total 169 with the category Very Eligible from Material Experts and have an average percentage of $85.20 \%$. The assessment of media experts got a score of 150 out of a total 161 in the Very Eligible category and had an average $94.83 \%$. The product field test, respondents gave a value of 109.3 out of a total of 136 in the Eligible category and average of $80 \%$.

\section{References}

[1] Abdul Majid. Perencanaan Pembelajaran. Bandung: PT Remaja Rosdakarya. (2006)

[2] Arief S. Sadiman, dkk. Media Pendidikan: Pengertian, Pengembangan, dan Pemanfaatannya. Jakarta: PT Raja Grafindo Persada. (2014)

[3] Arikunto, S. Prosedur Penelitian: Suatu Pendekatan Praktik (Edisi. Rev). Jakarta: Rineka Cipta. (2010)

[4] Azhar Arsyad. Media Pembelajaran (Rev.ed). Jakarta: Raja Grafindo Persada. (2017)

[5] Baharuddin. Teori Belajar dan Pembelajaran. Yogyakarta: Ar-Ruzz Media. (2008)

[6] Borg \& Gall. Education Research, New York: Allyn and Bacon. (2003)

[7] Busyairi, Ahmad. Pengembangan Modul Pembelajaran Kontekstual Berbantuan Kompuer Untuk Membantu Pemahaman Konsep Dinamika Rotasi Benda Tegar. S1 thesis, Fakultas Teknik. UNY. (2012)

[8] Chomsin S.Widodo dan Jasmadi. Panduan Menyusun Bahan Ajar Berbasis Kompetensi. Jakarta: Gramedia. (2008)

[9] Danim, Sudarwan. Pengantar Kependidikan. Bandung : Alfabeta. (2010)

[10] David, Prins S. Angka Kecelakaan Kerja RI Meningkat Ke 123 Ribu Kasus di 2017 di akses via: https://m.detik.com/ginance/moneter/d- 3853101/angka-kecelakaan-kerjari-meningkat-ke-123-ribu-kasus-di-2017/ diakses 30 Maret pukul 17.00 WIB. (2018)

[11] Daryanto. Media Pembelajaran. Bandung: PT. Sarana Tutorial Nurani Sejahtera. (2013)

[12] Departemen Pendidikan Nasional. Pedoman Memilih dan Menyusun Bahan Ajar. Jakarta: Direktorat Sekolah Menengah Pertama, Direktorat Jenderal Manajemen Pendidikan Dasar dan Menengah, Departemen Pendidikan Nasional. (2008)

[13] BNSP (Badan Standar Nasional Pendidikan). Panduan Penyusunan Kurikulum Tingkat Satuan Pendidikan Jenjang Pendidikan Dasar dan Menengah. Jakarta. (2007) 
